\title{
HEMATOLOGY AND PRODUCTIVE PERFORMANCE OF NILE TILAPIA (Oreochromis niloticus) NATURALLY INFECTED WITH Flavobacterium columnare
}

\author{
F. A. Sebastião ${ }^{1}$; D. Nomura ${ }^{2}$; R. Sakabe ${ }^{2}$; F. Pilarski ${ }^{2} *$ \\ ${ }^{1}$ Programa de Pós-Graduação em Microbiologia Aplicada à Agropecuária, Universidade Estadual Paulista, Jaboticabal, SP, Brasil; \\ ${ }^{2}$ Centro de Aqüicultura, Universidade Estadual Paulista, Jaboticabal, SP, Brasil.
}

Submitted: March 04, 2010; Returned to authors for corrections: March 31, 2010; Approved: June 21, 2010.

\begin{abstract}
Columnaris disease is one of the main causes of mortality in tilapia rearing and is responsible for large economic losses worldwide. Hematology is a tool that makes it possible to study organisms' physiological responses to pathogens. It may assist in making diagnoses and prognoses on diseases in fish populations. The hematological variables of nile tilapia were studied in specimens with a clinical diagnosis of columnaris disease and in specimens that were disease-free. The total erythrocyte count, hemoglobin rate, hematocrit percentage, mean corpuscular hemoglobin $(\mathrm{MCH})$, mean corpuscular hemoglobin concentration (MCHC), mean corpuscular volume (MCV), organic defense blood cell percentages (leukocytes and thrombocytes) and hepatosomatic and splenosomatic index were determined. The results showed that there were changes in the erythrocytic series and in organic defense blood cells, in the fish infected with the bacterium, with reductions in erythrocytic variables and significant increases in the numbers of circulating lymphocytes and neutrophils.
\end{abstract}

Key words: Fish, bacteria, hematology, productive performance

\section{INTRODUCTION}

Flavobacterium columnare is the bacterium responsible for columnaris disease, an important bacterial disease that occurs worldwide. It has a large economic impact on fish production because of the extensive and rapid rate of mortality that it causes $(4,48)$. The clinical signs of the disease begin with corrosion of the dorsal and tail fins, and this progresses to external infection in which gray spots or yellowed areas of erosion appear, generally surrounded by a hyperemic reddened zone, in the cranial region, body surface and gills. In these locations, there is progressive necrosis involving the epidermis, dermis and musculature (34).
Brazil is a country where favorable conditions exist for a wide diversity of fish production systems. However, major challenges are faced, particularly in relation to bacterial infections. Among these is columnaris disease, one of the biggest obstacles to future growth in this activity (11).

$F$. columnare is a long non-flagellate Gram-negative bacillus that presents the principal characteristic of motility by means of "gliding" or sliding along solid surfaces (2). The characteristics that differentiate it from other bacteria are its ability to grow in the presence of neomycin sulfate and polymyxin B sulfate, its production of rhizoid colonies with yellowish pigmentation, its production of an enzyme that degrades gelatin and chondroitin B sulfate and its absorption of 
Congo red into its colonies (19).

In Brazil, this bacterium was first isolated by Pilarski (30), in four species of tropical fish. Since then, the disease has gradually been increasing in prevalence in this country, with the passing of the years (11). F. columnare is considered to be an opportunist bacterium and forms part of the normal microbiota in water and soil, and in the skin, intestine and gills of fish (6). However, under unfavorable conditions such as temperatures higher than $20^{\circ} \mathrm{C}$, reduced dissolved oxygen levels, elevated ammonia concentrations, elevated population density, contamination with other bacteria, eutrophic environments or damage caused to the body surface of fish, the bacterium is able to invade the host and trigger epizootic diseases $(15,52,53)$.

Columnaris disease is considered important in relation to tilapia rearing (13). However, there are no data in the literature regarding the hematological variables of tilapia infected by $F$. columnare. Although teleost fish have been widely studied, there is a scarcity of data in the literature on the hematology of their inflammatory and infectious responses. The hematological parameters of fish may be of great value in relation to fish farming, since they may be used as indicators of physiological conditions and for monitoring diseases and the stress caused by handling (40). For this reason, the present study had the aim of establishing hematological reference values for tilapias with a clinical diagnosis of columnaris disease and analyzing the weight gain, length and hepatosomatic and splenosomatic index of these fish with bacterial infection.

\section{MATERIAL AND METHODS}

For this study, 30 specimens of nile tilapia were used, weighting approximately $263.68 \pm 22.18 \mathrm{~g}$. They were kept in five fiber boxes of capacity $310 \mathrm{~L}$ that were supplied with water from an artesian well at a flow rate of one liter/minute, with continuous aeration. They were supplied with commercial feed at the rate of $3 \%$ of biomass. The experiment was conducted at the State University of São Paulo (UNESP), Jaboticabal Campus, State of São Paulo (SP).
Before starting the experiment, six specimens of tilapia with a diagnosis of columnaris disease were sent to the Fish Microbiology Laboratory of the School of Agrarian and Veterinary Sciences (FCAV), UNESP, Jaboticabal, SP, for isolation of the bacterium. These fish were euthanasied by means of an overdose of anesthesia and then soaked in a solution of iodated alcohol and subsequently dried on sterile gauze. They were then placed under a laminar flow hood, where they were examined anatomopathologically. Approximately $0.5 \mathrm{~g}$ of cephalic kidney fragments were collected from each specimen for seeding in liquid culture medium in accordance with Anacker \& Ordal (1955) (3), as modified by Pilarski et al. (2008) (30), with incubation at $28^{\circ} \mathrm{C}$ for 48 hours. After this period, the material was cultured in modified agar medium $(10,30)$ on Petri dishes $(95 \times 15 \mathrm{~mm})$ at $28^{\circ} \mathrm{C}$ for 48 hours. Suspicious colonies were selected and transferred into test tubes $(13 \times 100 \mathrm{~mm})$ containing $2.0 \mathrm{ml}$ of slanted nutrient agar. The seeding was performed by means of puncture using a platinum loop, with subsequent incubation at $28^{\circ} \mathrm{C}$ for 48 hours.

After obtaining pure cultures, the strains isolated were characterized by means of cell bacterioscopy. The cultural characteristics in the modified liquid and solid medium of Anacker \& Ordal (1955) (3) were assessed. Motility was evaluated. Biochemical tests were performed, such as $\mathrm{H}_{2} \mathrm{~S}$ production, citrate, indole, lysine decarboxylation, flexirrubin and Congo red absorption, among others. The bacterium $F$. columnare was isolated from all six cephalic kidney samples that were examined, and thus the fish were considered suitable for starting the experiment.

\section{Blood collection}

The tilapia were anesthetized in a benzocaine solution (1 $\mathrm{g} / 10 \mathrm{~L})$. After immobilization, biometry was performed and around $2.0 \mathrm{ml}$ of blood was withdrawn by means of puncturing the caudal vessels, using syringes and sterilized needles. From these samples, one drop was used for blood smears that were air-dried and stained using Rosenfeld's (33) procedure, for 10 minutes. Then, under an optical microscope, differential 
leukocyte counts and thrombocyte counts were performed, for up to 200 cells. Total leukocytes, thrombocytes and erythrocytes were quantified indirectly from the same smears, in terms of the numbers of thrombocytes, leukocytes and erythrocytes per 2000 cells.

Another aliquot was placed in an Eppendorf tube containing heparin (5000 IU). This was homogenized and stored on ice for immediate hematocrit determination using the microhematocrit method, in accordance with Goldenfarb (18), and for determining the hemoglobin rate $(\mathrm{Hb})$ and mean corpuscular volume (MCV) using an automatic blood cell counter (Model CC510, Celm). After collecting the blood, a necropsy was performed on the fish, to remove the liver and spleen, which were immediately weighed.

The results obtained were subjected to analysis of variance. The $\mathrm{F}$ values that indicated significant differences $(\mathrm{P}$
$<0.01)$ were subjected to the Duncan test to compare the means. The statistical analyses on all of the results were performed using the SAS 6.01 software (Statistical Analysis System).

\section{RESULTS AND DISCUSSION}

The physicochemical variables of the water in the boxes were shown to be adequate for the wellbeing of nile tilapia, in accordance with Sipaúba-Tavares (36), with the exception of the temperature, which presented a large amplitude of variation over the day. The mean temperature was $28 \pm 6.42^{\circ} \mathrm{C}$, the concentration of dissolved oxygen was $4.8 \pm 2.4 \mathrm{mg} / \mathrm{L}$ and the $\mathrm{pH}$ was $7.4 \pm 1.2$.

The mean values and coefficient of variation of the productive performance of the tilapia with columnaris disease and the tilapia free from infection are reported in Table 1.

Table 1. Means, standard deviations, $F$ values and coefficients of variation (CV) of the variables of productive performance, hepatosomatic index and splenosomatic index for tilapia with natural infection by Flavobacterium columnare and tilapia free from infection.

\begin{tabular}{cccccc}
\hline Treatment & N & Weight & Total length & HSI & SSI \\
\hline F for treatment & & 11.85 & 6.94 & 7.72 & 0.29 \\
CV & & 28.94 & 9.07 & 27.27 & 36.50 \\
Means for : & & & & $0.016^{* *}$ & $( \pm 0.00009)$ \\
Infected fish (1) & 20 & $229.78^{* *}$ & $22.78^{* *}$ & $( \pm 0.004)$ & $0.00025^{\mathrm{ns}}$ \\
Uninfected fish (2) & 10 & $331.50^{* *}$ & $24.95^{* *}$ & $0.011^{* *}$ & $( \pm 0.00006)$ \\
\end{tabular}

$\mathrm{N}$ - number of fish; HSI - hepatosomatic index; SSI - splenosomatic index

$* * \mathrm{P}<0.01 ; \mathrm{ns}-$ not significant

The weight gain and length were significantly affected by columnaris disease. Thus, the infected fish presented weights and lengths that were significantly smaller than those of the healthy fish. It was therefore seen that the bacterium had a negative effect on the productive performance index, thereby reducing the growth and weight gain of the infected fish and causing low productivity and economic losses (28).
The hepatosomatic index was also significantly affected by columnaris disease, such that the diseased fish presented values that were higher than those in the fish that were free from infection. On the other hand, the splenosomatic index did not present any significant difference between the diseased and healthy fish. It is important to determine standard values for the hepatosomatic index in order to understand liver disorders that 
might occur during pathological processes (30).

Diseases are responsible for growth retardation in several species of fish $(22,37)$. They reduce the general wellbeing of fish (35) because they reduce the food intake, impair digestibility and negatively affect other physiological processes that have a variety of manifestations. These go from retarding weight gain to premature death (41).
The columnaris disease did not significantly influence the mean erythrocyte count, hematocrit percentage or hemoglobin rate in the tilapia, as can be seen in Table 2. However, all the above variables were seen to present lower values in the fish affected by columnaris disease. According to Rehulka (32), this is normal in fish when there is some type of infection, as also observed in the present experiment.

Table 2. Means, standard deviations, $\mathrm{F}$ values and coefficients of variation (CV) for the following hematological variables among tilapia with natural infection by Flavobacterium columnare and tilapia free from infection: erythrocyte count (Eryth), hematocrit (Ht), hemoglobin concentration ( $\mathrm{HgB})$, mean corpuscular volume (MCV), mean corpuscular hemoglobin (MCH), mean corpuscular hemoglobin concentration (MCHC) and thrombocytes (Thromb).

\begin{tabular}{|c|c|c|c|c|c|c|c|c|}
\hline & $\mathbf{N}$ & $\begin{array}{c}\text { Eryth } \\
\left(10^{6} / \mu \mathrm{l}\right)\end{array}$ & $\begin{array}{l}\text { Ht } \\
(\%)\end{array}$ & $\begin{array}{l}\text { HgB } \\
(g / d l)\end{array}$ & $\begin{array}{c}\text { MCV } \\
\text { (fl) }\end{array}$ & $\begin{array}{c}\text { MCH } \\
(\mathbf{p g})\end{array}$ & $\begin{array}{c}\text { MCHC } \\
\text { (g/dl) }\end{array}$ & $\begin{array}{c}\text { Thromb } \\
(\mu \mathrm{l})\end{array}$ \\
\hline $\mathrm{F}$ for treatment & & 1.73 & 2.29 & 0.52 & 0.52 & 3.16 & 5.35 & 0.34 \\
\hline \multicolumn{9}{|l|}{ Means for: } \\
\hline Infected fish & 20 & $\begin{array}{c}1.81^{\mathrm{ns}} \\
( \pm 0.20)\end{array}$ & $\begin{array}{l}35.80^{\mathrm{ns}} \\
( \pm 4.50)\end{array}$ & $\begin{array}{c}1.93^{\mathrm{ns}} \\
( \pm 0.21)\end{array}$ & $\begin{array}{l}197.97^{\mathrm{ns}} \\
( \pm 18.33)\end{array}$ & $\begin{array}{c}52.17 * * * \\
( \pm 3.24)\end{array}$ & $\begin{array}{c}5.15 * \\
( \pm 0.21)\end{array}$ & $\begin{array}{l}0.18^{\mathrm{ns}} \\
( \pm 0.07)\end{array}$ \\
\hline Uninfected fish & 10 & $\begin{array}{c}1.93^{\mathrm{ns}} \\
( \pm 0.27)\end{array}$ & $\begin{array}{l}38.50^{\mathrm{ns}} \\
( \pm 4.81)\end{array}$ & $\begin{array}{c}1.99^{\mathrm{ns}} \\
( \pm 0.23)\end{array}$ & $\begin{array}{l}204.38^{\mathrm{ns}} \\
( \pm 27.11)\end{array}$ & $\begin{array}{c}55.75 * * * \\
( \pm 6.97)\end{array}$ & $\begin{array}{c}5.35^{*} \\
( \pm 0.22)\end{array}$ & $\begin{array}{c}0.17^{\mathrm{ns}} \\
( \pm 0.07)\end{array}$ \\
\hline
\end{tabular}

$* \mathrm{P}<0.05$ and $>0.01 ; * * * \mathrm{P}<0.09 ; \mathrm{ns}-$ not significant

With regard to the number of thrombocytes, although there was no significant difference between the infected and uninfected fish, it can be seen that this number was larger among the infected fish. In teleost fish, thrombocytes have been acquiring importance as organic defense cells. The high number of these cells in circulation $(26,46)$, their marked presence in inflammatory exudates $(9,24)$, the presence of lysosomal enzymes and glycogen granules in their cytoplasm and the endocytosis and digestion of cell remains that occur suggest that these cells participate in removing undesirable elements from the organism (45). Higher numbers of these cells in the circulation of fish infected by the bacterium may have an important role in relation to defense mechanisms. This would suggest that thrombocytes moved in order to perform phagocytosis and help in combating bacteria in the organism of the tilapia.

Regarding the absolute blood measurement index (MCV, $\mathrm{MCH}$ and $\mathrm{MCHC}$ ), it could be seen that there were significant differences in mean corpuscular hemoglobin $(\mathrm{MCH})$ and mean corpuscular hemoglobin concentration (MCHC) between the fish with columnaris disease and those that were free from infection, such that the latter presented higher values.

The hematocrit percentage, hemoglobin rate and erythrocyte count are good indicators for the oxygen transportation capacity of fish, thus making it possible to establish relationships with the oxygen concentration available in the habitat and the health status of these fish (22). In the present study, with the reductions in erythrocyte count and 
hemoglobin rate, it was noted that the oxygen carrying capacity was impaired by the infection, which was also observed in studying the occurrence of hematological changes in tilapia infected by the bacterium Streptococcus iniae (27). Reductions in the erythrocyte count, hematocrit percentage and hemoglobin rate indicate that fish infected with the bacterium F. columnare are developing anemic states (50). Thus, from the results obtained, it can be supposed that there is an imbalance in the parasite-host relationship, such that the bacterium causes severe damage to its host.

The use of hematological parameters for diagnosing the state of health of fish is accepted worldwide. Regular monitoring of these parameters may optimize fish production (1), since this makes it possible to gain knowledge about the normal and pathological equilibrium conditions (4) and about their association with the environment within which the fish live (45).
In mammals and fish, infectious diseases activate the cell immunological system, thereby changing the percentage of circulating blood cells that provide organic defense (7). For this reason, there is a need to identify and quantify blood cells for organic defense, in both healthy and diseased fish, in order to gain better understanding of cell participation in pathological processes.

In the present study, regarding the numbers of blood cells for organic defense, the tilapia with columnaris disease presented mean total leukocyte counts that were significantly greater than those in healthy tilapia (Table 3), as also observed by Mattsson (25). Leukocytosis was observed when tambaqui (Colossoma macropomum) were subjected to the stimulus of capture (42). Their response to this stressful stimulus was to contract the spleen through sympathetic action and release leukocytes into the bloodstream (17).

Table 3. Means, standard deviations, $F$ values and coefficients of variation $(\mathrm{CV})$ of blood cells for organic defense in tilapia with natural infection by Flavobacterium columnare and tilapia free from infection.

\begin{tabular}{|c|c|c|c|c|c|}
\hline Treatment & $\mathbf{N}$ & $\begin{array}{c}\text { Total leuk } \\
\left(10^{4} / \mu \mathrm{l}\right)\end{array}$ & $\begin{array}{l}\text { Lymph } \\
\left(10^{6} / \mu \mathrm{l}\right)\end{array}$ & $\begin{array}{c}\text { Neu } \\
\left(10^{6} / \mu \mathrm{l}\right)\end{array}$ & $\begin{array}{c}\text { Mon } \\
\left(10^{6} / \mu \mathrm{l}\right)\end{array}$ \\
\hline $\mathrm{F}$ for treatment & & 3.94 & 5.07 & 3.04 & 1.25 \\
\hline $\mathrm{CV}$ & & 47.47 & 37.27 & 65.69 & 65.90 \\
\hline \multicolumn{6}{|l|}{ Means for: } \\
\hline \multirow[t]{2}{*}{ Infected fish } & 20 & $2.95^{*}$ & $2.14^{*}$ & $1.30 * * *$ & $1.19^{\mathrm{ns}}$ \\
\hline & & $( \pm 1.43)$ & $( \pm 0.80)$ & $( \pm 0.87)$ & $( \pm 0.76)$ \\
\hline \multirow[t]{2}{*}{ Uninfected fish } & 10 & $1.95 *$ & $1.48 *$ & $0.77 * * *$ & $0.87^{\mathrm{ns}}$ \\
\hline & & $( \pm 0.71)$ & $( \pm 0.50)$ & $( \pm 0.33)$ & $( \pm 0.60)$ \\
\hline
\end{tabular}

Total leuk - total number of leukocytes; Lymph - lymphocytes, Neu - neutrophils, Mon - monocytes $\quad *(\mathrm{P}<0.05) ; * * *(\mathrm{P}<0.09) ;$ ns - not significant

The number of neutrophils was significantly greater in the infected tilapia. Increased numbers of these cells are generally associated with disease (31), and this could clearly be seen in the present study.

Depending on the species and environmental characteristics, lymphocytes may be the most frequent type of leukocyte in the peripheral blood of fish (31). In the present study, circulating lymphocytes were the most abundant type of leukocyte in the peripheral blood of tilapia infected with columnaris disease, and their levels were higher than is normally reported in tilapia $(39,44,49)$. In fish, lymphocytes participate in inflammatory processes (23), although the function of these cells remains unclear (45). It is possible that they are recruited to the focus of the lysate by the defense 
mechanisms, which might explain the high numbers of these cells in the blood circulation of the infected tilapia.

In tissues, mononuclear cells (lymphocytes and macrophages) predominate in the organism's defense reactions. However, in stressful situations, the number of circulating lymphocytes decreases $(4,21)$. Therefore, considering the conditions of the present study and the environment to which these fish were exposed, it is possible to infer that they might not have displayed any stress response. This would explain the leukocytosis in the fish with columnaris disease. Despite the varied response presented, i.e. sometimes a decrease and sometimes an increase in the number of cells (Table 3), this phenomenon may be indicative of attempts by the organism to adapt to the infection.

Carp subjected to stress due to capture or transportation have been found to present increased percentages of neutrophils in their blood, in the same way as seen in the present study (38). This author reported the occurrence of lymphopenia, i.e. the opposite of what was seen with tilapias.

There was no significant difference in the number of monocytes between the fish infected by the bacterium and those without infection. However, the number of monocytes was much greater in the infected fish. The increased number of monocytes, which are phagocytic cells, may have been due to intensification of the cell defense mechanism, as suggested by Souza (38) in relation to parasitized Cyprinus carpio. Pacu infested with Argulus sp. were found to show increased percentages of monocytes and special granulocytic cells (40).

The results from the present study contrast with the majority of other studies consulted, in that parasitized fish have generally been seen to present lower numbers of organic defense cells, compared with healthy fish. In fact, the opposite was observed in the present study: all the defense cells studied were present in larger quantities in the fish infected with the bacterium. It was not possible to discuss the data from this study in relation to any studies correlating bacterial infections with hematological parameters, because of the difficulty in finding such studies in the literature.

In the present study, neither infected nor healthy tilapia presented eosinophils and basophils. These cell types were also not found in peripheral blood of the fry of $M$. curema parasitized by Gyrodactylus curemae (12). Furthermore, these cells were the least frequent type of leukocyte in the circulation of 11 teleosts (44).

Increased susceptibility of fish to diseases results from the immunosuppression caused by stress. In the present study, variation in the water temperature, particularly during colder periods in the winter, was considered to be the main stressful factor for the tilapia and the consequent cause of their illness. This can be shown through analysis of the leukograms of the fish.

The fish affected by columnaris disease presented abnormal hematological values. In other words, the organism was incapable of maintaining erythropoiesis at levels considered adequate for this species. There is a need to identify the blood cells for organic defense in every teleost species under normal conditions, in order to understand the behavior of cell populations when undergoing morbid processes (43). For this reason, in the present study we compared tilapia infected with the bacterium $F$. columnare with tilapia free from infection.

\section{CONCLUSION}

The bacterium $F$. columnare causes significant changes to the hematological characteristics and productive performance of infected tilapia.

\section{REFERENCES}

1. Adebayo, O.; Faqbenro, O.A.; Ajavi, C.B.; Popoola, O.M. (2007). Normal haematological profile of Parachanna obscura as a diagnostic tool in aquaculture. Int. J. Zool. Res. 3(4),193-199.

2. Amend, D.F. (1982). Columnaris (Flexibacter columnaris) disease of freshwater fishes and a brief review of other flexibacterial diseases of fish. Symposium International de Talloires, Collection foundation, Marcel Merieux, Lyon, p.139-161

3. Anacker, R.L.; Ordal, E.J. (1955). Study of bacteriophage infecting the Mycobacterium chondrococcus colummaris. J. Bacteriol. 70(6), 738-741.

4. Arias, C.; Welker, T.L.; Shoemaker, C.A.; Abernathy, J.W.; Klesius, 
P.H. (2004). Genetic fingerprinting of Flavobacterium columnare isolates from cultured fish. J. Appl. Microbiol. 97, 421-428.

5. Azevedo, T.M.P.; Martins, M.L.; Yamashita, M.M.; Francisco, C.J. (2006). Hematologia de Oreochromis niloticus: comparação entre peixes mantidos em piscicultura consorciada com suínos e em pesque-pague no vale do rio Tijucas, Santa Catarina, Brasil. Bol. Inst. de Pesca, 32 (1), 4149.

6. Barja, J.L.; Estevez-Toranzo, A. (1988). Enfermedades bacterianas de peces. In: Pellitero, A.P.; Barja, J.L.; Blanch, A.; Estevez-Toranzo, A.; Giorgetti, G.; Torroella, J.J. (eds.). Patologia en Acuicultura. Madrid, J. Espinosa de los Monteros \& U. Labata, p. 475-521.

7. Bertolini, J.M.; Rohovec, J.S. (1992). Electrophoretic detection of proteases from different Flexibacter columnaris strains and assessment of their variability. Dis. Aquat. Org., 12, 121-128.

8. Boon, J.H.; Cannaerts, V.M.H.; Augustijn, H.; Machiels, M.A.M.; De Charleroy, D.; Olliver, F. (1990). The effect of different infection levels with infective larvae of Anguillicola creassus on haematological parameters of European eel (Anguilla anguilla). Aquacult. 87, 243-253.

9. Bozzo, F.R.; Moraes, J.R.E.; Moraes, F.R.; Pereira, G. T.; Tavares-Dias, M.; Onaka, E.M. (2007). Kinetics of cellular component in inflammatory response induced by different stimuli in the swin bladder of pacu Piaractus mesopotamicus Holmberg, 1887 (Characidae). J. Worl. Aquat. Soc. 38 (2), 302-308.

10. Ceccarelli, P.S.; Adriano, E.A.; Santos, S.M.C.; Rego, R.F.; Silva, L.O.L (2007). Levantamento Quali-Quantitativo da fauna parasitológica de peixes do pantanal Mato-Grossense. In: Pesquisas patológicas e genéticas em recursos pesqueiros da Bacia do Alto Paraguai/Centro de Pesquisa e Gestão de Recursos Pesqueiros Continentais. Pirassununga, Ibama, p. 21$124 \mathrm{p}$.

11. Conroy, G; Conroy, D.A. (1985). Gyrodactylosis in silver mullet (Mugil curema Val.) from Venezuelan coastal waters and a decription of Gyrodactylus curemae n. sp. Riv. Ital. Pisc. Ittiopatol. 20 (4), 140-147.

12. Chun, S.K.; Sohn, S.G. Characteristics of Flexibacter columnaris isolated from tilapia (Tilapia sp). Bull. Korean Fish. Soc. 18, 369-373.

13. Davis, H.S. (1922). A new bacterial disease of fresh water fishes.U.S. Bureau Fish. Bull. 28, 261-280.

14. Durborow, R.M.; Thune, R.L.; Hawke, J.P.; Camus, A.C. (1998). Columnaris disease: a bacterial infection caused by Flavobacterium columnare. South. Reg. Aquacult. Center. 479, 31-44.

15. Fish, F.F.; Rucker, R.R. (1943). Columnaris as a disease of cold water fishes. Am. Fish Soc. 73, 32-36.

16. Fujimoto, R.Y.; Castro, M.P.; Martins, M.L.; Moares, F.R.; Monfort, K.C.F. (2007). Parâmetros sanguíneos de pacu Piaractus mesopotamicus (Holmberg, 1887) alimentados com dietas suplementadas com cromo trivalente em duas densidades de estocagem. Acta Scient. 29 (4), 465471.

17. Goldenfarb, P.B.; Bowyer, F.P.; Hall, E.; Brosious, E. (1971). Reproducibility in the hematology laboratory: The micro-haematocrit determinations. Am. J. Clin. Pathol. 56, 35-39.

18. Griffin, B.R. (1992). A simple procedure for identification of Cytophaga columnaris. J. Aquat. Anim. Health. 4, 63-66.

19. Houston, A.H.; Dobric, N.; Kahurananga, R. (1997). The nature of hematological response in fish. Fish Physiol. Bioch. 14 (4), 339-347.

20. Iwama, G.; Nakanishi, T. 1996. The fish immune system. London; Academic Press, 380p.

21. Klesius, P.; Rogers, W. 1995. Parasitism of catfish and other farm-raised food fish. J.A.V.M.A., 207 (11), 1473-1478.

22. Lamas, J.; Santos, Y.; Bruno, D.W.; Toranzo, A.E.; Anadon, R. (1994). Non-specific cellular responses of rainbow trout to Vibrio anguillarum and its extracellular products (ECPs). J. Fish. Biol. 45 (5), 839-854.

23. Martins, M.L. (2000). Efeito da suplementação com vitamina C sobre a reação inflamatória em Piaractus mespotamicus Holmberg, 1887 estressados. Jaboticabal, São Paulo, Brasil, 145p. (Dr Thesis. Centro de Aqüicultura da Unesp. Caunesp).

24. Mattsson, K.; Lehtinen, K.J.; Tana, J.; Härdig, J.; Kukkonen, J.; Nakari, T.; Engström, C. (2001). Effects of pulp mill effluents and restricted diet on growth and physiology of rainbow trout (Oncorhynchus mykiss). Ecotoxicol. Environ. Saf. 49, 144-154.

25. Matushima, E.R.; Mariano, M. (1996). Kinetics of the inflammatory reaction induced by carrageenin in the swimbladder of Oreochromis niloticus (Nile tilapia). Brazilian J. Res. Anim. Sci. 33 (1), 5-10.

26. Mcnulty, S.T.; Klesius, P.H.; Shoemaker, C.A. (2003). Hematological changes in Nile tilapia (Oreochromis niloticus) infected with Streptococcus iniae by nare inoculation. J. Wor. Aquacult. Soc. 34 (3), 418-422.

27. Perry, B.D.; Randolph, T.F. (1999).Improving the assessment of the economic impact of parasitic disease and of their control in production animals. Vet. Parasitol. 84, 145-168.

28. Pilarski, F.; Rossini, A.J.; Ceccarelli, P.S. (2008). Isolation and characterization of Flavobacterium columnare (Bernardet et al. 2002) from four tropical fish species in Brazil. Brazilian J. Biol. 68 (2), 631637.

29. Quentel, C.; Obach, A. (1992). The cellular composition of the blood and haematopoietic organs of turbot Scophthalmus maximus L. J. Fish Biol. 41, 709-716.

30. Ranzani-Paiva, M.J.T.; Souza, A.T.S.; Pavanelli, G.C.; Takemoto, R.M. (2000). Hematological characteristics and relative condition factor (Kn) associated with parasitism in Schizodon borellii (Osteichthyes, Anostomidae) and Prochilodus lineatus (Osteichthyes, Prochilodontidae) from Paraná river, Paraná, Brazil. Acta Scient. 22 (2), 515-521.

31. Rehulka, J. (1996). Blood parameters in common carp with spontaneous spring viremia (SVC). Aquacult. 4, 175-182.

32. Rosenfeld, G. (1947). Corante pancrômico para hematologia e citologia clínica. Nova combinação dos components do May-Grunwald e do Giemsa num só corante de emprego rápido. Mem. Inst. But. 20, 329-334.

33. Schneck J.L.; Caslake L.F. (2006) Genetic diversity of Flavobacterium 
columnare isolated from fish collected from warm and cold water. J. Fish Dis. 29, 245-249.

34. Singhal, R.N.; Jeet, S.; Davies, R.W. (1990). The effects of argulosissaprolegniosis on the growth and production of Cyprinus carpio. Hydrobiol. 202, 27-31.

35. Sipaúba-Tavares, L.H. (1995). Limnologia aplicada à aquicultura. Jaboticabal, Funep, 70p.

36. Souza, M.L.R.; Martins, M.L.; Santos, J.M. (1997). Scanning eletronic microscopy of Trichodina spp in branchiae of the pacu (Piaractus mesopotamicus). Acta Microscopica, 6:516-517.

37. Sopinska, A. (1984). Effects physiological factors, stress and disease on hematologic parameters of carp, with a particular reference to the leukocyte patterns. III. Changes in blood accompanyng branchionecrosis and bothriocephalosis. Acta Ichthyol. Piscat. 15 (2), 141-165.

38. Tavares-Dias, M.; Faustino, C.D. (1998). Parâmetros hematológicos da tilápia-do-Nilo Oreochromis niloticus (Cichlidae) em cultivo extensivo. Ars. Vet. 14 (3), 254-263.

39. Tavares-Dias, M.; Schalch, S.H.C.; Martins, M.L.; Silva, E.D.; Moraes, F.R.; Perecin, D. (1999). Hematologia de teleósteos brasileiros com infecção parasitária. I. Variáveis de Leporinus macrocephalus Garavello \& Britski, 1988 (Anostomidae) e Piaractus mesopotamicus Holmberg, 1887 (Characidae). Acta Scient. 21, 337-342.

40. Tavares-Dias, M. (2000). Estudos parasitológicos e hematológicos em peixes oriundos de "pesque-pagues" do município de Franca, São Paulo. Jaboticabal, São Paulo, Brasil, 130p. (M.Sc. Dissertation. Centro de Aquicultura da Unesp).

41. Tavares-Dias, M.; Sandrim, E.F.S.; Moraes, F.R.; Carneiro, P.C.F. (2001). Physiological responses of stress. Bol. Inst. Pesca, 27 (1), 43-48.

42. Tavares-dias, M.; Melo, J.F.M.; Moraes, G.; Moraes, F.R. (2002). Haematological characteristics of brazilian teleosts.VI. Parameters of jundiá rhamdia quelen (pimelodidae). Cien. Rur. 32 (4), 693-698.

43. Tavares-Dias, M. (2003). Variáveis hematológicas de teleósteos brasileiros de importância zootécnica. Jaboticabal, São Paulo, Brasil, 209p. (Ph.D. Thesis. Centro de Aqüicultura da Unesp).

44. Tavares-Dias, M.; Moraes, F.R. (2003). Características hematológicas da Tilápia rendalli Boulenger, 1896 (Osteichthyes: Cichlidae) capturada em pesque-pague de Franca, São Paulo, Brasil. Biosc. J. 19 (1), 107-114.

45. Tavares-Dias, M.; Moraes, F.R. (2004). Hematologia de Peixes Teleósteos. Ribeirão Preto, M. Tavares, 144 p.

46. Tavares-Dias, M.; Ono, E.A.; Pilarski, F.; Moraes, F.R. (2007). Can thrombocytes participate in the removal of cellular debris in the blood circulation of teleost fish? A cytochemical study and ultrastructural analysis. J. Appl. Ichthyol., p.1-4.

47. Thomas-Jinu, S.; Goodwin, A.E. (2004). Morphological and genetic characteristics of Flavobacterium columnare isolates: correlations with virulence in fish. J. Fish Dis. 27, 29-35.

48. Ueda, I.K.; Egami, M.I.; Sasso, W.S.; Matushima, E.R. (1997). Estudos hematológicos em Oreochromis niloticus (Linnaeus, 1758) (Cichlidae, Teleostei) - Parte I. Braz. J. Vet. Res. Anim. Sci. 35 (5), 270-275.

49. Vosyliene, M.Z. (1999). The effect of heavy metals on haematological indices of fish. Acta Zool. Lituan. Hydrobiol. 9 (2), 76-82.

50. Wakabayashi, H.; Egusa, S. (1972). Preliminary experiments on environmental factors influencing the prevalence of columnaris disease. Fish Pathol. 7, 58-63.

51. Wakabayashi, H. (1991). Effect of environmental conditions on the infectivity of Flexibacter columnaris to fish. J. Fish Dis. 14, 279-290.

52. Zhao, G.; Chung, K.T.; Milow, K.; Wang, W.; Stevens, S.E. (1997). Antibacterial properties of tannic acid and related compounds against the fish pathogen Cytophaga columnaris. J. Aquatic Anim. Health. 9, 309313. 